\title{
Sme's Growth Pattern as a Success Business Indicator Through Sharia Economic in Reducing Poverty in Indonesia
}

\author{
Endah Meiria \\ Lecturer of UIN Syarif Hidayatullah Jakarta \\ Abdul Hamid \\ Proffesor of UIN Syarif Hidayatullah Jakarta \\ Riris Aishah \\ Lecturer of UIN Syarif Hidayatullah Jakarta
}

\begin{abstract}
This study aims to explain and prove the correlation and the effect of the growth pattern of the SMEs (Small and Medium Enterprises) sector on the determinants of successful business through sharia economics and to determine the right variables in reducing poverty in Indonesia. The object of this research is poverty reduction variables and success business determinants in the tertiary sector of SMEs, namely services and trade. This study uses quantitative and qualitative methods, where the quantitative method uses random effect estimation method and the level of validity is tested using AR and JB tests. The expected results of this study are able to explain quantitatively and to prove the assumption of significant growth pattern of the micro small and medium enterprises sector to achieve a successful business through sharia economics on poverty reduction in Indonesia which has a positive correlation, in line with the assumption that successful SMEs through sharia economics also shows positive and significant results. This result will be analyzed qualitatively which is equipped with a foundation of fiqh.
\end{abstract}

Keywords: Indonesian SMEs (Micro, Small, Medium Enterprises), successful business, SMEs (Micro, Small, Medium Enterprises) growth, poverty reduction, sharia economy.

\section{INTRODUCTION}

SMEs (Small and Medium Enterprises) are one of the economic actor entities who has dominance over the nation's economy, both in urban and rural areas (Isnawan, 2012). Small or medium-scale businesses (SMEs) have an important role in economic development, absorb a large number of labors and contribute to GDP and prosperity growth and improvement. The contribution of SMEs is not only monetary, but also a driver of innovation in business.

So far, SMEs have contributed to the Gross Domestic Product (PBD) of 57-60\% and the labor absorption rate is around $97 \%$ of the entire national workforce (Business Profile of SMEs by the LPPI and BI in 2015). Not much different from Kadin records (Indonesian Chamber of Commerce), the contribution of the MSME sector to gross domestic product increased by $57.84 \%$ to $60.34 \%$ in the last five years. Absorption of labor in this sector also increased from $96.99 \%$ to $97.22 \%$ in the same period. For 2 decades since 1992 until now Islamic banking has been able to finance SMEs as much as 32\% compared to Conventional banks. So this study focuses on the portion that can still be achieved by capital or Islamic-based SMEs financing as the potential and growth prospects of sharia-based SMEs.

The role and the development of SMEs is very strategic in helping the national economy to alleviate poverty, and also can improve the standard of living and competitiveness of a group of 
business units that can accelerate the equitable distribution of economic growth through the mission of providing employment (Hubeis, 2009). In Islam, the recommendations of work and business are special concern to every human being on the earth, Islam teaches that by working, everyone can get assets that can be used for their survival both individually and socially, Allah SWT says in Surah Al-Mulk verse 15 "It is He Who has made the earth manageable for you, so traverse ye through its tracts and enjoy of the Sustenance which He furnishes."

\section{THEORITICAL REVIEW}

\section{Affecting Factors the Success of SME Businesses}

Related studies based on surveys have discussed the factors that influence the success of SMEs. Nurul Indarti and Marja Langenberg (2005) identify the key components to be important in analyzing the success of SME businesses that include the characteristics of entrepreneurs; characteristics of SMEs; and contextual elements of SME development. Westhead (1995) studied the facts that influenced the survival of 227 small high-tech companies. Ghosh and Kwan (1996) made cross-national cross-sectional assessments of the main success factors of 152 SMEs in Singapore and 164 SMEs in Australia. Kauranen (1996) conducted a follow-up study of 37 new manufacturing companies in Finland and studied the determinants of the company's future success in the short and long term. Yusuf (1995) explores critical success factors for small companies in several industrial sectors based on the perception of 220 South Pacific entrepreneurs. Wijewardena and Cooray (1996) examined the importance of a series of success factors by studying samples from 300 small manufacturing companies in Japan. Gadenne (1998) examined the influence of various management practices on small companies by studying 369 small businesses in the retail, service and manufacturing industries in Australia. Bracker and Pearson (1986) studied the planning and financial performance of small adult companies in the dry cleaning business. Baker et al. (1993) studied planning in small, successful high-growth companies. Pelham (2000) advocates the relationship between market orientation and the performance of manufacturing SMEs in 8 industrial sectors.

This study uses Jasra et al., (2011) which shows that Financial Resources (Lewis \& Algaoud, 2001; Thurik, 2007; Usman \& Ali, 2008; Gait \& Worthington, 2008, 2009; Hanif \& Iqbal, 2010; Mirakhor \& Iqbal, 2011; Awang, et. Al., 2016), Marketing Strategies (Johnson \& Scholes, 1993; Auger, et. Al., 2003; Hayami, 2009; Jurado, et. Al., 2015), Technology Resources (Li \& Ye, 1999; Premkumar \& Roberts, 1999; Hitt \& Brynjolfsson, 2000; Napier et, al., 2001; Rashid \& Al-Qirim, 2001; Sakai, 2002; Huggins, 2007; Cartsson, 2008; Joseph, 2009; ), Government Support (Deakin \& Hughes, 1997; FCGI, 2001; Tjager, et. Al., 2003; Solomon, 2004; Daniri, 2005; Abor \& Adjasi, 2007; Arafat, 2008; Butler, 2008; Effendi, 2009; Sedarmayanti, 2012), Information Access (Salminen, 2000; Deakins, 2006), Business Plan (Chami, 2006; Yussof \& Yacob, 2010), and Entrepreneurial Ability (Cromie, 2000; McMahon, 2001; Lumpkin \& Dess, 2001; Kristiansen, et. al., 2003; Kristiansen \& Indarti, 2004; Deakins, 2006; Curran , 2007), as a determinant of successfull business. This study also includes Shariah Compliance variables as elements of business success in sharia economics.

\section{Fiqh Rules Determine the Success of SME Businesses}

The role and development of small and medium businesses is starategis in helping the national economy, the business world can also improve the standard of living and competitiveness for a group of business units to accelerate equitable economic growth through a mission of providing job vacancy (Hubeis, 2009). Islam suggests that working and effort become a particular concern for every human being on earth, Islam taught that by working everyone can get an assets that can be used for survival, both individually and socially, Allah says in Surah AlMulk verse 15: "It is He Who has made the earth manageable for you, so traverse ye through its 
tracts and enjoy of the Sustenance which He furnishes". In seeking the sustance, Islam's rule is to see the halal aspects of both the raw material sources, the process, and the management and expenditure. Allah says in Surah Al-A'raf verse 10 "And We have certainly established you upon the earth and made for you therein ways of livelihood. Little are you grateful". In another verse the letter Al-Maidah verse 88 "And eat of what Allah has provided for you [which is] lawful and good". Islam emphasizes lawfulness and good quality to ensure the benefit of humanity as a whole in a text of business. Also proved in the rules of fiqh "laa dharara walaa dhirar" means that it should not be harmful or not harmful to each other (Hidayatullah 2012). The business in Islam has rules based on the Qur'an and hadith to make a benefit and avoid the difficulties, in society or transaction. Also proved by the rules of fiqh "al ashlu fil manafi 'al Hillu wa fii al madharri attahriim". Basically, all that is useful is permissible and all that is harmful or danger is prohibited "(Hidayatullah, 2012).

\section{Sharia Compliance}

Over the past few decades, the development of Islamic finance has shown changes and dramatic dynamics rapidly. As a part of the instrument for developing activities in the economic field, various challenges are faced by the Islamic financial system, such as in the theoretical, operational and implementation aspects. In the theoretical aspect, it is necessary to develop the principles, philosophies and functions of the financial system on the basis of the distribution of profits and losses. On the operational side, attention is needed to innovation, intermediation, discipline and risk control, while on the implementation side it is necessary to apply systems that must be adjusted to regulations, and the current economic conditions of the community.

In terms of capital, SMEs in Indonesia can utilize Islamic banking services in financing their business. If conventional financial institutions only have one principle, namely interest, then in Islamic financial institutions there is a choice of principles that can be appropriated to the customer needs, namely the principle of profit sharing, the principle of buying and selling, the principle of lease and the principle of service. In 2012 Bank Indonesia recorded loans by commercial banks to SMEs reached Rp. 552.2 Trillion, while for Islamic banks it has distributed loans to SMEs of Rp. 135.58 Trillion (Bank Indonesia, 2012). Many types of sharia-based and conventional financing are expected to help industries to develop his business. In addition, the industry is expected to be able to choose carefully the financing that can provide good benefits for the industry.

Sharia compliance here is not only in the technical aspects such as financing, recording, transactions, etc., but it also can be seen in terms of how the entrepreneur runs his business, both in terms of products ranging from raw materials to finished products, how to market them, how to treat employees and customers, to small things such as cleanliness, personal and business daily to the core of the business, namely giving benefits and blessing oriented in the world and the hereafter.

\section{Affecting Factors the Success of SME's Business towards Poverty Reduction}

In terms of poverty reduction, poverty reduction variables in this study use Mosley, et. al. (2004) namely GDP, Pro-poor spending, public health spending, lack of corruption, low income, population, and Islamic macro policies, which are also supported by Watson (2002), Burnside \& Dollar (1998), Collier (2002), Wedgwood (2005), Jalilian \& Kickpatrick (2001), World Bank (1999), Deininger \& Okidi (2005), Weiss \& Montgomery (2004), Montalvo \& Ravallion (2009). 


\section{Gross Domestic Product (GDP)}

Economic growth is one of the macroeconomic indicators that illustrates the growth of production of goods and services, in an economic region within a certain time interval. Economic growth is a long-term economic problem of a country. Economic growth measures the achievement of the development of an economy from one period to the next. This growth is the ability of a country to produce goods and services which will increase due to factors of production that always has an increase in the number and quality. Economic growth as a process of increasing output over the time becomes an important indicator to measure the success of a country's development (Todaro, 2005).

\section{Pro Poor Expenditures}

Pro poor budget can be defined as a budget made for the poor. The Pro Poor Budget is a political action that aims to allocate rights and resources to individuals, organizations and territories that are marginalized by the market and the state.

\section{Public Health Expenditures}

Health has a very important role in creating quality human resources. Poor health conditions will create low quality human resources. Unhealthy children will have an obstacle of education in school, so the quality of education will also decrease. Likewise with employment, an unhealthy labor will not be able to work optimally, so that the productivity of the labor will be low. Conditions like this in the future will have a great opportunity to inhibit the process of economic development of the country. Relates to this matter, in order to achieve the establishment of economic development, it must be prioritized by improving the quality of human resources, especially in the health sector.

\section{The Absence of Corruption}

Corruption is simply understood as an attempt to use the ability to intervene because of its position to misuse information, decision, influence, money or wealth for the benefit of its own benefit (Haryatmoko 2011: 123). Corruption occurs because the abuse of authority is not for the common interest, but for its own interest.

\section{Low Income}

Economic growth is one indicator of the successful development in each country. Government efforts to increase the level of welfare of its people are reflected in economic growth that can be achieved. The higher level of economic growth means the higher level of people's welfare. Therefore all of establishment activities must focus on efforts to increase economic growth, one of, which is by developing SMEs. Economic growth is a process that causes a rise in real per capita income of a country's population in the long run. Rapid economic growth cannot necessarily successful in development. In the past decade, the government's efforts to increase Indonesia's economic growth have been relatively improved with an average growth rate of $5.8 \%$ per year (Ginting \& Aji, 2015).

\section{Population}

Population is a region that is general in nature consisting of subjects or objects with certain characteristics (Sugiyono, 2005). Indonesia's population growth rate between 2000 and 2010 is around 1.49 percent per year. The highest growth occurred in Papua province (5.46 percent), while the lowest population growth occurred in Central Java province (0.37 percent). The Family Planning Program (KB) is coordinated by government institutions, namely the National Population and Family Planning Board (BKKBN). The family planning program began in 1968 during the reign of President Suharto and is still being carried on by its successors. 
This program - which (unfortunately) cannot be obliged - is an important strategy for Indonesia's economic growth because low population growth will lead to higher levels of GDP per capita, which will also increase income, savings, investment and reduce poverty. Population growth is estimated at around 1.2 percent in 2015 based on World Bank data.

\section{Effect of Entrepreneurial Ability on Poverty Populations}

The positive socio-economic impact of entrepreneurship is to create jobs, improve quality of life, increase income equity, utilize and mobilize resources to increase national productivity, and improve the welfare of government through government programs, such as taxes and others. And reduce poverty, because with the positive impact of entrepreneurship, the job seekers who were originally only interested in the formal sector are expected to change their views and switch to the informal sector. According to Stephen R. Covey, these changes are often a painful process. It is a change that must be motivated by a higher goal, by the willingness to subordinate what you think you want now to what you want later.

\section{Sharia Macro Policy}

Islamic macro policy is a policy issued by the government which includes all aspects of the national economy. Several types of policies are often known as fiscal policies, monetary policies, and international trade policies. Each of these policies play different roles, but the aim of all these policies is the same, is to realize the acceleration of the growth of the domestic economy.

\section{METHODOLOGY}

This study aims to determine the impact of successful SME businesses on poverty reduction. The selection of variables that are relevant to successful SME business theory with the poverty reduction theory by involving sharia compliance and sharia policies as far as the SMEs are known and understood in the service sector and trade sector randomly in the target areas of research, among others: Yogyakarta, Palembang, Bengkulu, Makassar, Lombok / Bali, Bandung, Balikpapan and Jabodetabek. The selection of this region is assumed because these areas have many SME centers, and it is assumed that each region has similar characteristics of SMEs.

This study uses primary data in the form of a questionnaire as a latent variable that describes: gross domestic production, pro-poor spending, public health spending, lack of corruption, low income, population, and sharia policy as an Islamic macro variable observed to measure poverty reduction, as well as latent variables of successful business determinants of SMEs such as: financial resources, technology sources, marketing strategies, government support, access to information, business plans, and sharia compliance.

To get the goodness of fit from this study used soft modeling with Partial Least Squares (PLS) analysis method in testing several theories such as SME business success theory and the theory of poverty alleviation, also in testing sample data representing regions in Indonesia. This PLS method is used to explain the relationship between latent variables (reduction) and confirm the theory in this study.

This study aims to examine the correlation and determinant of the success or success of SME business by adding indicators of measurement of sharia compliance to poverty alleviation which are also included in sharia macro policy indicators. For this purpose, this study establishes the following hypothesis:

1. Hypothesis for growth patterns with business determinants of Sharia-based success for SMEs in Indonesia: 
H10: Sharia-based successful business determinants are not correlated and have no effect on SME Business in Indonesia

H1a: Sharia-based successful business determinants correlate and influence the SME Business in Indonesia.

2. Hypothesis for Sharia-based SMEs in Indonesia against Poverty Reduction:

H20: Sharia-based SMEs are not correlated and have no effect on poverty reduction

H2a: Sharia-based SMEs correlate and influence poverty reduction.

3. Hypothesis Growth patterns with business determinants Sharia-based SMEs Success in reducing poverty:

H30: Successful business determinants of Sharia-based SMEs are not correlated and have no effect on poverty reduction

H3a: Successful business determinants of Sharia-based SMEs correlate and influence poverty reduction

\section{RESEARCH RESULT}

\section{Measurement Model / Instrument Quality Test Results (PLS Algorithm)}

The questionnaire was built as a construct for every item from each indicator to measure the variable of SMEs in the service and trade sector success and poverty reduction variables before the outer loading analysis was carried out based on the original sample results as follows:

Figure 1.

\section{Modeling Mode of Successful Business of SMEs towards Poverty Reduction after Elimination of Several Indicators}

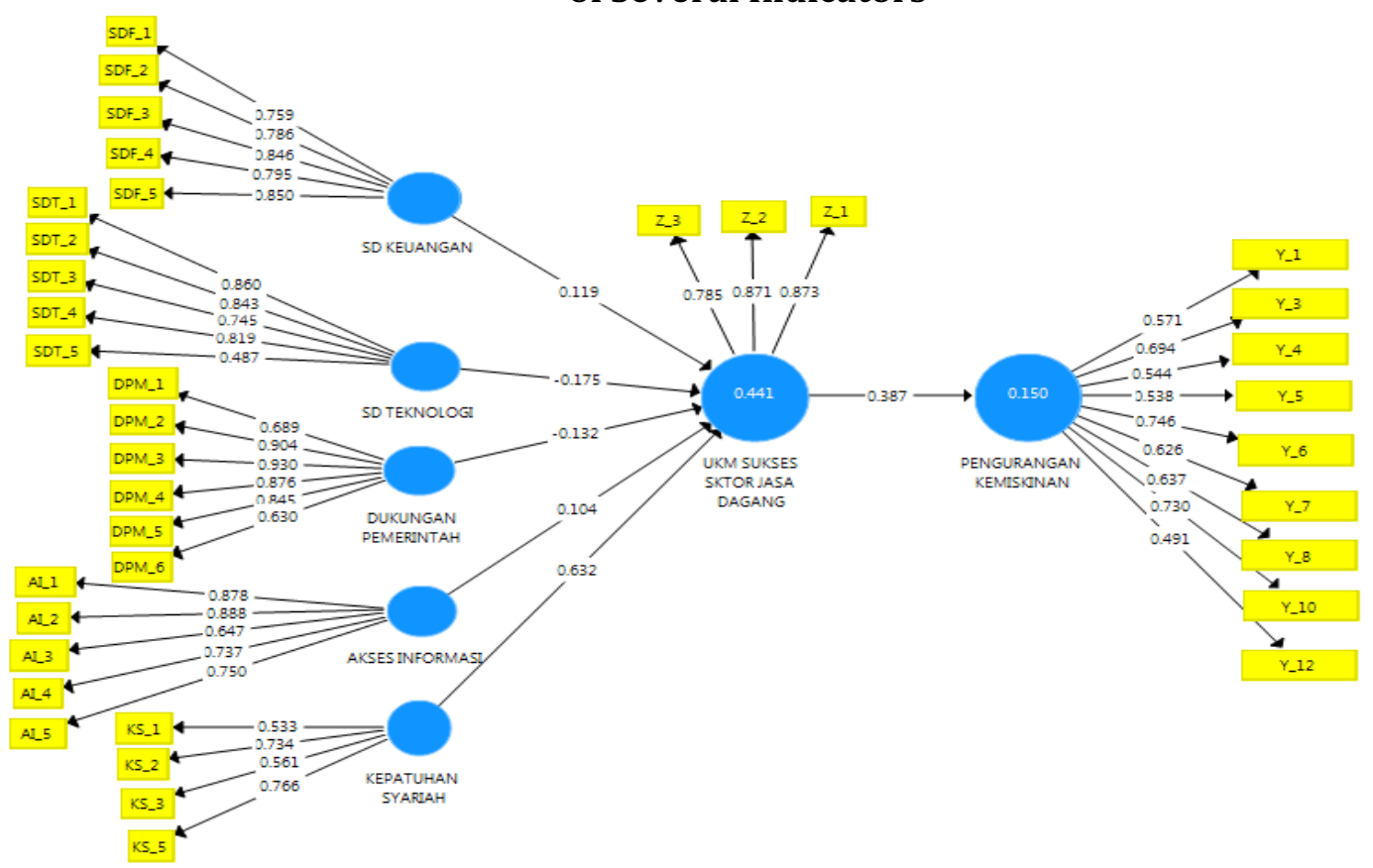

Source: Data processed, 2018

Outer loading analysis from Figure 1 Modeling mode shows items on the variable measurement indicator: $\mathrm{DP}=$ Marketing strategy, $\mathrm{KW}=$ entrepreneurial ability, $\mathrm{RB}=$ Business Plan, and $Y=$ Poverty Reduction has outer loading test results with a low score $<0.70$ ( Chin, 1998). The next three variables are: $\mathrm{DP}=$ marketing strategy, $\mathrm{KW}=$ entrepreneurial ability, and $\mathrm{RB}=$ Business Plan, eliminated for subsequent analysis measurements. However, to facilitate 
the testing of the next hypothesis, this study uses the outer loading assessment with a score of $>$ 0.50 , so that the variable $Y=$ poverty reduction in this study is not eliminated as a whole, some items from variable indicators that have a value $>0.50$ are still used for measurement Subsequent analysis as an object of measurement (indicator) of the variables measured is the successful business of SMEs in the service and trade sectors.

Some of the indicator items eliminated include:

1. Z4 item is a measuring indicator of service \& trade sector variables is the reluctance of SME entrepreneurs in making payment transactions in cash or installments with a good sharia contract.

2. Then the indicator item Y9 measures poverty reduction variables for measurement of SME entrepreneurs towards the payment system in business transactions using Islamic banks, SME business respondents generally answered that they did not use Islamic banks for business transactions in various research areas.

3. Item Y2 measuring indicators of poverty reduction variables used for SME businesses obtain subsidies / assistance / grants / financing programs from the central / regional government, respondents generally answer less especially for sharia-based subsidies / grants / assistance.

4. Item Y11 variable indicator of poverty reduction on the use of trade transactions out of the region or country of SMEs with a sharia contract, respondents in general answered that they did not use transactions between regions or sharia-based countries at all.

5. On the variable side of SME business success; SDT6 item is a measuring indicator of variable technology resources that measures the SME entrepreneurs using technology in developing their business, it turns out this indicator is eliminated because it has a very less assessment on SME respondents.

6. KS4 items measuring indicators of sharia compliance variables in not applying the interest system to SME businesses, this indicator is eliminated because respondents generally apply the interest system in their business.

These eliminated indicators show that when in the field even though the respondent responded positively, after processing it produced a low calculation, such as indicators of marketing strategies, entrepreneurial abilities, and business plans. This does not mean that the UKM does not have a marketing strategy, entrepreneurial ability, and a good business plan, only in reality the capabilities possessed are not documented and contained in a clear SOP, only limited to the 'thinking' of entrepreneurs, so that the strategy, ability, and the SME business plan runs according to the thinking, situation and business conditions at that time and is executed according to circumstances. This is sometimes what causes a business to stop in the middle of the road because it does not have an analysis such as vision, mission, and SWOT contained in the management of SMEs, so that when the control holder is not in place, the employee does not have a handle or guidelines in running the business or in solving problems .

Modeling mode above the results of the outer loading analysis shows the score or assessment on each indicator used so that in this study are as follows: 
Table 4.1

Outer Loading SME Successful Business Against Poverty Reduction

\begin{tabular}{|c|c|c|c|c|c|c|c|}
\hline Indikator & $\begin{array}{l}\text { AKSES } \\
\text { INFORMASI }\end{array}$ & $\begin{array}{l}\text { DUKUNGAN } \\
\text { PEMERINTAH }\end{array}$ & $\begin{array}{l}\text { KEPATUHAN } \\
\text { SYARIAH }\end{array}$ & $\begin{array}{l}\text { PENGURANGAN } \\
\text { KEMISKINAN }\end{array}$ & $\begin{array}{l}\text { SD } \\
\text { KEUANGAN }\end{array}$ & $\begin{array}{l}\text { SD } \\
\text { TEKNOLOGI }\end{array}$ & \begin{tabular}{|c|} 
UKM SUKSES \\
JASA\& \& \\
DAGANG
\end{tabular} \\
\hline$A I \_1$ & 0,878 & & & & & & \\
\hline$A I=2$ & 0,888 & & & & & & \\
\hline$A I 3$ & 0,647 & & & & & & \\
\hline $\mathrm{Al}^{\prime} 4$ & 0,737 & & & & & & \\
\hline$A I=5$ & 0,750 & & & & & & \\
\hline$\overline{D P M} 1$ & & 0,689 & & & & & \\
\hline DPM 2 & & 0,904 & & & & & \\
\hline DPM_3 & & 0,930 & & & & & \\
\hline DPM 4 & & 0,876 & & & & & \\
\hline DPM 5 & & 0,845 & & & & & \\
\hline DPM 6 & & 0,630 & & & & & \\
\hline$K S \_1$ & & & 0,533 & & & & \\
\hline KS_2 & & & 0,734 & & & & \\
\hline $\mathrm{KS}=3$ & & & 0,561 & & & & \\
\hline$k S \_5$ & & & 0,766 & & & & \\
\hline SDF 1 & & & & & 0,759 & & \\
\hline SDF 2 & & & & & 0,786 & & \\
\hline SDF_3 & & & & & 0,846 & & \\
\hline SDF 4 & & & & & 0,795 & & \\
\hline SDF_5 & & & & & 0,850 & & \\
\hline SDT_1 & & & & & & 0,860 & \\
\hline SDT 2 & & & & & & 0,843 & \\
\hline SDT 3 & & & & & & 0,745 & \\
\hline SDT_4 & & & & & & 0,819 & \\
\hline SDT_5 & & & & & & 0,487 & \\
\hline$Y=1$ & & & & 0,571 & & & \\
\hline$Y=11$ & & & & 0,730 & & & \\
\hline$Y=12$ & & & & 0,491 & & & \\
\hline$Y=3$ & & & & 0,694 & & & \\
\hline$y=4$ & & & & 0,544 & & & \\
\hline$y=5$ & & & & 0,538 & & & \\
\hline$Y=6$ & & & & 0,746 & & & \\
\hline$Y=7$ & & & & 0,626 & & & \\
\hline$Y 8$ & & & & 0,637 & & & \\
\hline$z$ & & & & & & & 0,873 \\
\hline$z=2$ & & & & & & & 0,871 \\
\hline$z$ & & & & & & & 0,785 \\
\hline
\end{tabular}

Source: Data processed, 2018

Based on table 1 shows the following results:

1. The AI_1 indicator about the use of information technology to expand communication networks in SMEs has a value of 0.878 , which means that indicators have a relationship and a strong influence on the success variable of SMEs is $87.8 \%$. This shows that the maximum utilization of information technology by SMEs will expand more the information network so that it will affect the success of these SMEs.

2. The AI_2 indicator about access to get the certain quality information has a value of 0.888 which means having a relationship and a strong influence on the success variables of SMEs by $88.8 \%$. This shows that the more quality information obtained by SME entrepreneurs will affect the success of SMEs.

3. The AI_3 indicator about access to the latest business information developments has a value of 0.647 which means having a relationship and sufficient influence on the success variables of SMEs by $64.7 \%$. This shows that the wider and faster access to information on business development obtained by business actors will affect the success of SMEs.

4. The AI_4 indicator about access to information from suppliers has a value of 0.737 , which means having a strong relationship and influence on the success variables of SMEs by $73.7 \%$. This shows that if businesses always update information from suppliers, it will affect the success of SMEs.

5. The AI_5 indicator of using social media to obtain information about the SME business has a value of 0.750 , which means having a relationship and a strong impact on the success variables of SMEs by 75\%. This shows that the maximum business actors utilize social media in running their businesses; it will affect the success of the SMEs they run.

6. The DPM_1 indicator of government support in providing financial assistance to SME businesses has a value of 0.689 which means having a relationship and sufficient effect on the success variables of SMEs by $68.9 \%$. This shows that the more government support in providing financial assistance to SMEs, the more success that the SMEs will achieve. 
7. The DPM_2 indicator of government support in coordinating with SME entrepreneurs has a value of 0.904 , which means having a relationship and a strong effect on the success variables of SMEs by $90.4 \%$. This shows that the better government coordinates with SMEs, the better the success rate of these SMEs.

8. The DPM_3 indicator of government support in being a facilitator between SMEs entrepreneurs and related parties has a value of 0.930 , which means having a relationship and a strong effect on the success variables of SMEs by $93.0 \%$. This shows that the more active the role of government as a facilitator of SMEs with related parties, the more success will be achieved by SMEs.

9. The DPM_4 indicator about government support in providing training / workshops / seminars for SMEs entrepreneurs has a value of 0.876 which means having a strong relationship and influence on the success variables of SMEs by $87.6 \%$. This shows that the more variety of training / workshops / seminars held for SMEs, it will also increase the entrepreneurial ability to achieve success in its business.

10. The DPM_5 indicator of government support in the standard of supervision of SMEs has a value of 0.845 which means having a relationship and a strong effect on the success variables of SMEs by $84.5 \%$. This shows that the better supervision standards carried out by the government, it will affect the quality and success of the SMEs.

11. The DPM_6 indicator of government support in providing a community forum for SME entrepreneurs has a value of 0.630 which means having a relationship and sufficient effect on the success variables of SMEs by $63.0 \%$. This shows that the wider container provided by the government for SMEs, the more success rate of SMEs will be, because there will be communication and good hearings in the community.

12. The KS_1 indicator of concerning sharia compliance regarding the use of halal certified raw materials by SMEs entrepreneurs has a value of 0.533 which means having a relationship and sufficient effect on the success variables of SMEs by $53.3 \%$. This shows that ownership of halal certification by SMEs will be more convincing consumers of the products offered so that consumers do not hesitate to buy these products. The more convinced consumers are about the products they want to buy, the higher level of sales and of course it will affect the success of the SMEs business.

13. The KS_2 indicator of sharia compliance in the management of business finance fairly and ethically by SMEs entrepreneurs has a value of 0.734 which means having a strong relationship and effect on the success variables of SMEs by $73.4 \%$. This shows that fair and ethics in financial management will promote the principle of clarified, no fraud, deception in financial reporting. It was reported as a profit if it is profitable, as well as when the loss was reported to be a loss, so that the management / business owner could determine the maximum business fund management strategy for the continuity of his business. If this is carried out and applied consistently, it will affect the success of the SMEs.

14. The KS_3 indicator of concerning sharia compliance in the application of business norms and ethics in SMEs has a value of 0.561 which means having a relationship and sufficient effect on the success variables of SMEs by $56.1 \%$. This shows that the better business norms and ethics that are applied in the company, the better relationship between SMEs doer internally, such as employees and management and also externally, such as consumers, suppliers, investors, and related parties. This good relationship will certainly affect the success of SMEs, in line with the Hadith that friendship will open the door of sustenance.

15. The KS_5 indicator of concerning sharia compliance in the production and selling halal products by SMEs has a value of 0.766 which means having a strong relationship and effect on the success variables of SMEs by $76.6 \%$. This shows that the importance of halal production and sales activities for Indonesian consumers, who are mostly Muslims 
who need to be convinced of the halal product to be purchased. Consumers are now more critical of the products they will buy. Not only need to be convinced the halal of its raw materials, but also the halal of the production process to its sales. So the more convinced consumers are about their products, the more convinced they will buy and it will certainly increase sales and affect the success of the SMEs.

16. The SDF_1 indicator of concerning financial resources in using of banking services and facilities in running SMEs has a value of 0.759 which means having a strong relationship and effect on the success variables of SMEs by 75.9\%. This shows that banking services and facilities are currently very useful for SME business transaction activities. The more maximum the SME doer use this banking facility, the more efficient, fast and effective business transaction traffic will more affect the success of these SMEs.

17. The SDF_2 indicator of financial resources in investing financial instruments by SMEs has a value of 0.786 which means having a relationship and a strong effect on the success variables of SMEs by 78.6\%. This shows that the better SMEs players maximize financial instruments in their investment, the better their health will be, so that it will affect the success of the SMEs business.

18. The SDF_3 indicator of concerning financial resources in the application of business financial bookkeeping in accordance with applicable accounting principles by SMEs has a value of 0.846 which means having a relationship and a strong effect on the success variables of SMEs by $84.6 \%$. This shows that the better business bookkeeping in accordance with generally accepted accounting principles, the better the financial reporting is made because it can be read and understood by interested parties, such as banks or investors. If the SME attaches financial statements that are made in accordance with the accounting principles that apply in seeking funds, investors will be able to read clearly about the health of the business. So that if approved, SMEs can get capital to increase their business which will certainly affect the success of the SME business.

19. The SDF_4 indicator of concerning financial resources is involving the generally applicable financial mechanism by SMEs has a value of 0.795 which means having a relationship and a strong effect on the success variable of SMEs of 79.5\%. This shows that the admitted financial mechanism in general will help interested parties in understanding the financial condition of SMEs so that if they have an interest in adding capital or investment later, a good mechanism will affect the success of the SMEs.

20. 20. The SDF_5 indicator of financial resources, all files in bookkeeping related to business finance by SMEs has a value of 0.850 which means having a relationship and a strong effect on the success variables of SMEs by $85.0 \%$. This shows that a good bookkeeping of all files is a form of business financial documentation that can determine what financial strategies are in line with business conditions. A good and effective strategy based on clear bookkeeping will affect the sustainability and success of the SMEs.

21. The SDT_1 indicator of technological resources in the utilization of regional networks to encourage SMEs businesses has a value of 0.860 which means having a relationship and a strong effect on the success variables of SMEs by $86.0 \%$. This shows that the better technology in utilization of regional networks, the more it will increasingly expanded in its SMEs business so that it will affect the success of these SMEs.

22. The SDT_2 indicator of technological resources in adopting the innovation of information technology in developing SMEs has a value of 0.843 which means having a strong relationship and effect on the success variables of SMEs by $84.3 \%$. This shows that the maximum SMEs in adopting the innovation of information technology, the greater chance of SMEs in developing their business, so that it will affect the success of SME business. 
23. The SDT_3 indicator of technological resources, especially in the utilization of information technology in marketing SME products has a value of 0.745 which means having a strong relationship and effect on the success variables of SMEs by $74.5 \%$. This shows that the better utilization of information technology in marketing its products, the more likely level of sales will affect the success of the SMEs.

24. The SDT_4 indicator of technological resources in the utilization of technology to monitor consumer tastes and behavior of its in the business of SMEs has a value of 0.819 which means having a strong relationship and effect on the success variables of SMEs by $81.9 \%$. This shows that consumer tastes and behavior can be monitored for changes and trends through the utilization of maximum technology such as social media, online news, and business websites and research results. This will help SMEs businesses fit their products to market tastes. If the marketed product is in demand, it will increase sales volume and affect the success of the UKM.

25. The SDT_5 indicator of technology resources in the utilization of technology to connect with the entrepreneurial network of SMEs has a value of 0.487 which means having a relationship and less effect on the success variables of SMEs by $48.7 \%$. This shows that the better relationship between entrepreneurs and the wider network of entrepreneurial SMEs by utilizing technology, the more it will affect the success rate of these SMEs.

26. The Y_1 indicator of SMEs entrepreneurial income which increased above the UMR (Minimum Wage) has a value of 0.571 which means having a relationship and sufficient effect on poverty reduction in Indonesia by 57.1\%. This shows that the more entrepreneurial income of SMEs, the more standard of living, means that their business can influence poverty reduction through the SMEs business.

27. The Y_3 indicator of SMEs entrepreneurs understanding about health cards, smart cards, and own the healthy home/business has a value of 0.694 which means having a relationship and sufficient effect on poverty reduction in Indonesia by $69.4 \%$. This shows that the more SMEs entrepreneurs understanding about health facilities provided by the government, the more increasingly awareness of SMEs entrepreneurs are for healthy living and applying them in their business environment so that this has an effect on reducing poverty through the SME business.

28. The Y_4 indicator of the licensing and financing of SMEs in the absence corruption region and the demand for gratuity has a value of 0.544 which means having a relationship and sufficient effect on poverty reduction in Indonesia by $54.4 \%$. This shows that the absence of corruption in the business sector SMEs indicates that government assistance and related parties are actually distributed to SMEs, so they are helped and this has an effect on reducing poverty through the SME business.

29. The Y_5 indicator of SMEs income can fulfill all the needs of daily family life and can save even has a value of 0.538 which means having a relationship and sufficient effect on poverty reduction in Indonesia by $53.8 \%$. This shows that the better ability of SMEs in fulfilling their life needs and can save even, signifying that they are have an adequate amoung with their businesses so that they have an effect on reducing poverty through the SMEs business.

30. The Y_6 indicator of land availability and space for living and business in the relevant SMEs area has a value of 0.746 which means having a strong relationship and effect on poverty reduction in Indonesia by $74.6 \%$. This shows that the wider and more availability of land and the space to live in the SMEs area, indicates that doer of SMEs can live properly so that affects poverty reduction through the SME business.

31. The Y_7 indicator of unemployment and lack of food in the relevant SME area has a value of 0.626 which means having a relationship and sufficient effect on poverty reduction in Indonesia by $62.6 \%$. This shows that the higher level of labor absorption 
through SMEs, which is turning can reduce hunger in the communities around SMEs, indicates that the SME business has an effect on reducing poverty through the SMEs business.

32. The Y_8 indicator of the safety and beauty of well-maintained environment in the area of the SMEs involved has a value of 0.637 which means having a relationship and sufficient effect on poverty reduction in Indonesia by $63.7 \%$. This shows that the more safety and beauty of a well-maintained environment around SMEs, signifying the more public awareness of the safety and beauty environment, because with the existence of these SMEs stimulates around economic growth both financially and way of life, so that this affects poverty through the SME business.

33. The Y_11 indicator of trade transactions outside the region or country of SMEs using the facilities of Islamic banks has a value of 0.730 which means having a strong relationship and effect on poverty reduction in Indonesia by $73.0 \%$. This shows that the more awareness of SMEs in utilizing sharia banking services and facilities for their transaction activities means that doer of SMEs take part in developing and advancing Islamic banks where this has an effect on improving the macroeconomy in sharia which also affects poverty reduction through the SMEs business.

34. The Y_12 indicator of products or services sold by SMEs always attend the halal and thoyyib aspects by providing a halal label with a value of 0.491 which means having a relationship and sufficient effect on poverty reduction in Indonesia by $49.1 \%$. This shows that the better level of awareness of SMEs principals on the halal and thoyyib aspects of their products, the better level of public awareness of health and a good way of life certainly affect the improvement of living standards so that it has an effect in reducing poverty through the SME business.

35. The Z_1 indicator of SMEs that prioritize service (positive self-image) towards consumers has a value of 0.873 which means having a strong relationship and effect on SMEs in the service and trade sectors of $87.3 \%$. This shows that the service and trade sector SMEs have good customer service so that consumers feel served and fulfilled their needs through the service and trade sector SMEs.

36. The Z_2 indicator of SMEs that notice customer satisfaction and loyalty has a value of 0.871 which means having a strong relationship and effect on SMEs in the service and trade sectors of $87.1 \%$. This shows that the service and trade sector SMEs notice customer satisfaction and loyalty so that consumers will always turn back to the service and trade sector SMEs in fulfilling their needs.

37. The Z_3 indicator of SMEs that provide good, attractive, and halal products or services to consumers has a value of 0.785 which means having a strong relationship and effect on the service sector and trade SMEs by $78.5 \%$. This shows that the service and trade sector SMEs can fulfil the consumers tastes and desires so that consumers feel satisfied with the products provided by these service and trade sector SMEs.

\section{CONCLUSION}

The determinants of SMEs success in Indonesia from 8 (eight) indicators tested in this study, such as: 1) Information Access, 2) Government support, 3) Entrepreneurial ability, 4) Business Plans, 5) Financial resources, 6) Technological Resources, 7) Marketing Strategies, 8) Sharia compliance. By the tolerance of the path coefficient value of the score $>0.50$, there are 3 (three) indicators that must be eliminated because they have a value of $<0.50$, i.e. indicators of entrepreneurial ability, indicators of business plans, and indicators of marketing strategies. In general, Indonesia SMEs business in achieving the success of SMEs entrepreneur has not considered or does not involve the indicators of entrepreneurial ability, not get used to using SMEs business plan indicators, and utilize marketing strategy indicators. In the sharia 
compliance indicator, the indicator items does not apply the interest system in the SMEs business, the respondents who are generally the owners of Indonesian SMEs showed their unwillingness to carry out this indicator item, so to continue the analysis of the calculation of the indicator items about not applying the interest system in the SMEs business is eliminated. In this study the service and trade sector were observed, are being mediators of poverty reduction variables. A construct indicator of the cash utilization and credit transaction, indicating that SMEs entrepreneurs are not willing to provide the alternative transaction, so that this indicator is eliminated as a measurement of service and trade sector indicators.

The indicators of poverty reduction variables in PLS algorithm analysis shows very low coefficient results, so this study does not use path coefficient rules> 0.70 (Chin, 1998), but tolerates path coefficient values of $>0.50$ to be able to carry out the analysis next calculation (Gozali, 2015). The poverty reduction variable has 12 (twelve) indicator items derived from constructs such as: GDP, Propoor Expenditures, Public Health Expenditures, Absence of Corruption, Low Income, Population, and Islamic Macro Policy.

Elimination of indicator items about gaining subsidies/assistance/grants/cheap financing from the central/regional government as a measurement of poverty reduction variables on propoor expenditure indicators turns out that SMEs entrepreneurs in Indonesia rarely get this assistance program, this is indicated by the very small score obtained. Furthermore, indicator items on payment systems in business transactions using Islamic banks to assess sharia macro policy indicators. In general, SME business respondents do not conduct their business transactions using Islamic banks, so this indicator is eliminated because the path coefficient is small $<0.50$. Indicator items about trade transactions between regions and countries using the sharia contract have a small coefficient value as well, so that it is eliminated as a measurement indicator of sharia macro policy indicators. In general means, SME entrepreneurs in Indonesia are not accustomed to or accept their business transactions by using sharia contracts.

The general conclusion is the determinants of successful SMEs, especially in the service and trade sectors, still have a positive and significant relationship and effect on poverty reduction in Indonesia. In particular, the shariah compliance indicator shows a relationship and a positive effect partially on poverty reduction in Indonesia.

\section{BIBLIOGRAPHY}

Abor and Adjasi. 2007.“Corporate Governance And The Small And Medium Enterprises Sector: Theory And Implications," Corpoarate Governance, Vol. 7(2), pp. 111-122.

Akhmad Daniri. 2005. Good Corporate Governance, Konsep dan Penerapannya dalam Konteks Indonesia, Cetakan pertama, Jakarta : Gloria Printing

Arafat, 2008, How To Implement Good Corporate Governance Effectively, Jakarta: Skyrocketing Publicher.

Auger, P., BarNir, A., \& Gallaugher, J. M. (2003). "Strategic orientation, competition”, and Internet-based electronic commerce: Information Technology and Management, Apr.-Jul., 4, (2), 139-146.

Aworn, Chuthamas Chittith; Md. Aminul Islam; Thiyada Keawchana; Dayang Hasliza Muhd Yusuf; "Factors Affecting Business Success of Small \& Medium Enterprises (SMEs) in Thailand", Asian Social Science Vol. 7, No. 5; May 2011

Burnside, Craig and Dollar, David. 1998. Aid, the incentives regime, and poverty reduction. Macroeconomics and Growth Group, The World Bank.

Butler, J. C. (2008). Psychometric Theory. New York: McGraw-Hill. Journal of Market Research Society 24(2): 98122

Brynjolfsson, Erik and Hitt, Lorin, Beyond Computation: Information Technology, Organizational Transformation and Business Performance, Journal of Economic Perspectives, Vol. 14, No. 4, pp. 23-48, 2000.

Cartsson, J. (2008). Qualitative Inquiry and Research Design. The Journal of small business finance, 2(1), $219-231$. 
Chami, (2006).Technological innovation in women-owned firms: Influence of entrepreneurial motivation and strategic intention, The International Journal of Entrepreneurship and Innovation, 4(1): 265-274.

Collier, Pail and Dollar, david. 2002. Aid, allocation and poverty reduction. European Economic Review. Elsevier.

Cromie, S. (2000). Assessing entrepreneurial inclinations: Some approaches and empirical evidence. European Journal of Work and Organizational Psychology, 9(1), 7-20.

Curran, M. (2007). Family enterprises as an important factor of the economic development: the case of Slovenia. Journal of Enterprising Culture, 11(2): 111-130.

Deakins, S. and Hughes, A. (1997) “Comparative corporate governance : an interdiciplinary agenda”, in Deakin, S. and Hughes,A (Eds), Enterprise and community: New Direction in Corporate Governance, Blackwell publishers, Oxford

Deakins, S. (2006).Competition and Knowledge in Javanese Rural Business. Singapore Journal of Tropical Geography, 23(1): 52-70.

Deininger, Klaus and Okidi, John. 2005. Growth and Poverty Reduction in Uganda. World Bank and Economic Policy Research Council, Kampala.

Effendi, 2009, The Power Of Good Corporate Governance Terori Dan Implementasi, Jakarta: Salemba Empat.

FCGI. 2002. Peranan Dewan Komisaris dan Komite Audit dalam Pelaksanaan Corporate Governance (Tata Kelola Perusahaan). Seri Tata Kelola Perusahaan (Corporate Governance) Jilid II.Jakarta.

Gait, A. and Worthington, A. (2008). An empirical survey of individual customer, business firms and financial institution attitudes towards Islamic methods of finance, International Journal of Social Economics, 35(11), 783808.

Gait, A. and Worthington, A. (2009). Libyan Business Firm Attitide towards Islamic Methods of Finance. Social Science Research Network. [Online]. Available at : http://ssrn.com/abstract $=1370752$

Hanif, M. and Iqbal, A.M. (2010). Islamic Financing and Business Framework : A Survey, European Journal of Social Sciences, 15 (4), 475-489.

Hayami, F. (2009). Overview of Social Cognitive Theory and Self-efficacy, International Journal of Management 12(1): $44-55$.

Hitt, M. \& D. Ireland. (2000). The intersection of entrepreneurship and strategic management research, in Handbook of entrepreneurship, D. Sexton \& H. Landström (eds.), 45-63. Oxford: Blackwell.

Huggins, R. (2007). the success and failure of policy-implanted inter-firm network initiatives: Journal of small business Management, 33(4): 211-236.

Irfan, F.I. and Man, Y.C. (2012). Halal Economy : Proof from Al-Quran and As- Sunnah anddemandstoutilizeitinparallel(Online).Availableat:http://upm.academia.edu/firfansishak/Papers/1274718/Ha lalEconomyProofFrom Al-QuranandAs-SunnahandDemandstoUtilizeitinParallel. (Date retrieved19thMarch 2012)

Jalilian, Hossein and Kickpatrick, Colin. 2001. Financial Development and Poverty Reduction in Developing Countries. Working Paper Series. Institute for Development Policy and Management.

Jasra, Javed Mahmood; Dr. Muhammad Asif Khan; Ahmed Imran Hunjra; Rana Aziz Ur Rehman; DR. Rauf - I Azam;" determinants of business success of small and medium enterprises", International Journal of Business and Social Science Vol. 2 No. 20; November 2011.

Jarvis,I.R., Mackenzie,S.B., and Podsakoff,P.M.2003."A critical review of construct indicators and measurement model misspecifications in marketing and consumer research," Journal of Consumer Research,(30:2),pp.199-218.

Johnson, G. and Scholes, K. (1993). Exploring Corporate Strategy (3rd ed). Prentice Hall Inc. Cambridge.

Joreskog,K.G., and Yang, F.1996. Nonlinear structural equation models: the Kenny-Judd model with interactin effect. In: G.A. Marcoulides \& R.E. Schumacker, (eds.), Advanced Structural Equation Modelling. Mahwah,NJ: Lawrence Erlbaum,pp.57-89.

Joesph P.T., Sj, Ecommerce, PHI, New Delhi, 2009.

Kristiansen, S., Furuholt, B., \& Wahid, F. (2003). In ternet cafe entrepreneurs: pioneers in information dissemination in Indonesia. The International Journal of Entrepreneurship and Innovation, 4(4), p.251-263. 
Kristiansen, S., \& Indarti, N. (2004). Entrepreneurial Intention among Indonesian and Norwegian Students. Journal of Enterprising Culture, 12(1).

Lewis M.K. and Algaoud L.M. (2001). Islamic Banking. Northampton, Massachusetts, USA: Edward Elgar Publishing Ltd.

Li M. and L.R.Ye. Information technology and firm performance: linking with environmental, strategic and managerial contexts, Information and Management 35, 1999, pp. 43 - 51.

Lumpkin, G. T., \& Dess, G. G. (2001). Linking Two Dimensions of Entrepreneurial Orientation to Firm Performance: The Moderating Role of Environment and Industry Life Cycle. Journal of Business Venturing, Vol. 16, No. 5: 429 451.

Mackenzie,S.B., Podsakoff,P.M., and Jarvis,C.B.2005."The Problem of measurement Model Misspecification in Behavioral and Organizational Research and some Recommended Solutions," Journal of Applied Psychology (90:4),pp.710-730.

Malaysia SME (2012). Malaysia records RM35.4 billion total export value for halal products for 2011, March 24April 6, 2012.

McMahon, R. G. P. (2001). Growth and performance of manufacturing SMEs: The influence of financial management characteristics. International Small Business Journal , 19(3), p.10-28.

Mirakhor, A. and Iqbal, Z. (2011). An Introduction To Islamic Finance : Theory and Practice. Singapore: John Wiley \& Sons.

Montalvo,Jose G \&Martin Ravallion; The Pattern of Growth and Poverty Reduction in China, Policy Research Working Paper 5069; The World BankDevelopment Research GroupDirector's Office, October 2009.

Mohd Daud Awang, Muhamad Nur Aiman Mohd Noor, Junaina Muhammad, Amalina Abdullah, Suhaimi Ab. Rahman, Mohamed Hisham Dato Yahya"Acceptance and application of Islamic financial planning among small and medium enterprises halal operator in of Malaysia” IJASOS- International E-Journal of Advances in Social Sciences, Vol.II, Issue 6, December 2016

Mosley,Paul., John Hudson ; and Arjan Verschoor (2004) ; Aid, Poverty reduction and the 'New conditionality'. The Economic Journal , 114 ( June ), F217-F243.Royal Economic Society 2004. Published by BlackwellPublishing, 9600 Garsington Road, Oxford OX4 2DQ, UK and 350 Main Street, Malden, MA 02148, USA.

Napier, H.A. Creating a Winning E-Business, Course technology, Boston. 2001.

Nurdin Aminudin, 2003, Corporate Governance PT. Astra National Breakthrough in Corporate Governance, Strategy Management an Performance management,GML Performance Consulting

Osman, M.R. and Ali, H. (2008), Exploring Muslim Entrepreneurs' knowledge and usage of Islamic Financing, Seminar Keusahawanan Islam II Peringkat Kebangsaaan, Universiti Malaya, 15 October 2008.

Premkumar G. and Margaret Roberts, Adoption of new information technologies in rural small businesses, Omega, Volume 27, Issue 4, pp 467-484, 1999.

Rashid, M., A., \& Al-Qirim, N., A. (2001). “E-commerce technology adoption framework by New Zealand small to medium size enterprises”, Research Letters in the Information Mathematical Science, vol. 2, pp. 63-70.

Ravallion, Martin, Chen, Shaohua, 1997. What can new survey data tell us about recent changes in distribution and poverty? World Bank Economic Review 11, 357-382.2007. China's (uneven) progress against poverty. Journal of Development Economics 82, 1-42.

Ryan, T. R. (1970). Intentional Behavior: An Approach to Human Motivation. New York: The Ronald Press Company.

Sakai, K. (2002). Global Industrial Restructuring: Implications for Small Firms, STI Working Papers. 4, OECD, Paris, [Online] Available: http://www.oecd.org/sti/working-papers

Salminen, A. (2000). Implementing Organizational and Operational Change - Critical Success Factors of Change Management. Helsinki University of Technology. Acta Polytechnica Skandinavica. Industrial Management and Business Administration Series No. 7. ISBN 951-666-540-3.

Sedarmayanti, 2012, Good Governance \& Good Corporate Governance " Kepemerintahan Yang Baik \& Tatakelola Perusahaan Yang Baik" Bagian Tiga Edisi Revisi, Bandung: CV Mandar Jaya.

Solomon and Solomon, 2004, Corporate Governance and Accountability, England: John Wiley and Sons Ltd.

Swierczek, F. W., \& Ha, T. T. (2003). Entrepreneurial orient ation, uncertainty avoida nce and firm performance: an analysis of Thai and Vietnamese SMEs. International Journal of En trepreneurship and Innovation , 4(1), p.46-58. 
Tennenhaus,M., Vinzia, V.E., Chatelin,Y.M., \& Lauro, C. 2005. PLS path modeling Coputational statistics and data analysis, 48: 159-205

Thurik, M. (2007).Policy Induced Constraints on Small Enterprise Development in Asian Developing Countries: Small Enterprise Development, Journal of Small Business, 5(2): 66-78.

Vega-Jurado, J.. Julio-Esparragoza, D., Paternina-Arboleda, C.D and Velez, M.C, (2015). Integrating Technology, Management and Marketing Innovation through Open Innovation Models. J. Technol. Manag. Innov., Vol. 10(4), 85-90.

Wedgwood, Ruth. 2005. Education and Poverty Reduction in Tanzania. UKFIET International Conference in Education and Development, Oxford.

Weiss, John and Montgomery, Heather. 2004. Great Expectation: Microfinance and Poverty Reduction in Asia and Latin America. ADB Institute. Discussion Paper No. 15

William G, James M, SusanM. (2005). Fundamentals of Business: Starting a Small Business. McGraw-Hill/Irwin: New York.

World Bank. 1999. Gender, Growth, and Poverty Reduction. Economic Policy and Social Management Human Development

Agustine, Eva M.S. “Persepsi Penggunaan Aplikasi Internet Untuk Pemasaran Produk Usaha Kecil Menengah". Seminar Nasional Aplikasi Teknologi Informasi, (SNATI 2007) ISSN: 1907-5022 Yogyakarta, 16 Juni 2007.

Djelantik, Sukawarsini. "Korupsi, Kemiskinan Dan Masalah Di Negara Berkembang”. Jurnal Administrasi Publik, Vol. 5, No. 1. 2008.

Hapsari, Paramita, Prandhy. Dan Abdul hakim. "Pengaruh Pertumbuhan Usaha Kecil Menengah (UKM) terhadap Pertumbuhan Ekonomi Daerah (Studi di Pemerintah Kota Batu)". Jurnal Administrasi Publik,. Vol. 17, No. 2. 2014.

Hidayah, Arini. "Penerapan Sistem Informasi Pemasaran Pada Usaha Kecil Menengah (UKM) Dipurwokerto". Jurnal Manajemen dan Bisnis Media Ekonomi, Volume. XVI, NO. 2. Juli 2016.

Lubis, Tona, Aurora dn Junaidi. "Pemanfaatan Teknologi Informasi pada Usaha Mikro Kecil dan Menengah di Kota Jambi". Jurnal Perspektif Pembiayaan dan Pembangunan Daerah, Vol. 3, No. 3. Januari-Maret 2016.

Lustianah, Meri. "Pengaruh Alokasi Pro-Poor Budget Terhadap Indeks Pembangunan Manusia (IPM) Dengan Pendapatan Asli Daerah (PAD) Sebagai Variabel Moderasi Ditinjau Dari Ekonomi Syariah". Jurnal Ekonomi dan Bisnis Islam, Volume. 1, No. 2. Juli-Desember 2016.

Nawatmi. "Pengaruh Korupsi Terhadap Pertumbuhan Ekonomi Studi Empiris Negara-Negara Asia Pasifik". Media Ekonomi Dan Manajemen, Vol. 31, No. 1. Januari 2016.

Nuryanti. "Peran E-Commerce Untuk Meningkatkan Daya Saing Usaha Kecil Dan Menengah (Ukm)". Jurnal Ekonomi, Volume. 21, Nomor. 4. Desember 2013.

Padriyansyah. "Analisis Penerapan Dan Perkembangan Pro-Poor Budgeting Di Provinsi Sumatera Selatan Tahun 2009-2013". Jurnal Ilmiah Ekonomi Global Masa Kini, Volume, 06, No.01. Desember 2015.

Pebruati, Sri, Eka, dan Siti Ragil Handayani. "Pengaruh Aplikasi Teknologi Informasi Dalam Peningkatan Daya Saing Perusahaan (Studi Pada Ukm Kota Malang)” Jurnal Profit, Volume. 7, No. 1. 2010.

Roosdhani, Rifqy, Mohamad dan Purwo Adi Wibowo. "Analisis Tingkat Penggunaan Teknologi Informasi Dan Komunikasi Pada Usaha Kecil Menengah Di Kab. Jepara". Jurnal Dinamika Ekonomi \& Bisnis, Vol. 9 No. 2 Oktober 2012.

Sidiqqoh, Siti, Ati. Dan Doni Purnama Alamsyah. “Peningkatan Kinerja Bisnis Usaha Mikro Melalui Kajian Komitmen Dan Abisius Pengusaha”. Jurnal Ecodemica, Vol. 1, No. 2. September 2017.

Siregar, Ridwan. "Penggunaan Sistem Dan Teknologi Informasi Untuk Usaha Kecil Dan Menengah". Jurnal Wawasan, Volume. 11, Nomor. 2. Oktober 2005.

Supriyanto. "Business Plan Sebagai Langkah Awal Memulai Usaha". Jurnal Ekonomi \& Pendidikan, Volume. 6, Nomor. 1, April 2009.

Sugiarti, Yayak. "Kemiskinan Sebagai Salah Satu Penyebab Timbulnya Tindak Kejahatan". Jendela Hukum" Fakultas Hukum Unija, Volume. I, Nomor. 1. April 2014

Wahyuningsih, Sri. "Peranan UKM Dalam Perekonomian Indonesia". Jurnal Ilmu - ilmu Pertanian, Vol. 5, No. 1. 2009. 
https://www.bps.go.id/

http://validnews.co/

https://antikorupsi.org

https://news.detik.com

https://bandungkota.bps.go.id/

https://portal.bandung.go.id/

www.apjii.or.id/

www.pikiran-rakyat.com 